УДК 371

\title{
ФОРМИРОВАНИЕ ЭКОЛОГИЧЕСКИХ КОМПЕТЕНЦИЙ КАК КЛЮЧЕВОЙ ОРИЕНТИР РАЗВИТИЯ ФУНКЦИОНАЛЬНОЙ ГРАМОТНОСТИ ОБУЧАЮЩИХСЯ
}

\section{Бородина Галина Владимировна}

учитель биологии высшей квалификационной категории

МАОУ «СОШ № 12 им. Семенова В.Н.»

\begin{abstract}
Аннотация: Функциональная грамотность является одним из ключевых компонентов естественнонаучной грамотности, которая подразумевает творческую, наблюдательную личность, умеющую проявлять личное отношение к сохранению окружающей среды. Поэтому, формирование экологической компетенции сегодня является наиболее значимой задачей, так как нарушение экологического равновесия на нашей планете остается одной из самых острых проблем.
\end{abstract}

Ключевые слова: экологические компетенции, функциональная грамотность, экологическое сознание, экологическая культура.

\section{FORMATION OF ENVIRONMENTAL COMPETENCIES AS A KEY GUIDELINE FOR THE DEVELOPMENT OF FUNCTIONAL LITERACY OF STUDENTS}

\section{Borodina Galina Vladimirovna}

\begin{abstract}
Functional literacy is one of the key components of natural science literacy, which implies a creative, observant person who is able to show a personal attitude to the preservation of the environment. Therefore, the formation of environmental competence today is the most significant task, since the violation of the ecological balance on our planet remains one of the most acute problems.
\end{abstract}

Key words: ecological competence, functional literacy, ecological consciousness, ecological culture.

\section{Введение}

В современных условиях, в мире нестабильности, мы однозначно можем и должны обучать наше подрастающее поколение функциональной 
грамотности. Так как мы не можем точно предсказать, какие профессии будут нужны в будущем, какие профессиональные и прикладные навыки потребуются для построения успешной траектории своего развития. Формирование функциональной грамотности дает возможность воспитывать инициативную, самостоятельно творчески мыслящую личность, умеющую свободно решать жизненные задачи в различных условиях.

В международных исследованиях функциональной грамотности PISA является одним из ключевых компонентов естественнонаучной грамотности, которая подразумевает творческую, наблюдательную личность, умеющую проявлять личное отношение к сохранению окружающей среды, занимающая активную жизненную позицию, как гражданина своей Родины.

Формирование экологической компетенции личности к природе сегодня является наиболее значимой задачей, так как нарушение экологического равновесия на нашей планете остается одной из самых острых проблем. Поэтому каждый человек должен иметь определенный уровень экологических компетенций, формирование которых начинается с детства и продолжается всю жизнь. Это подтверждает актуальность темы работы.

Цель: воспитание гуманного, творческого, социально активного человека, уважительно и бережно относящегося к среде своего обитания.

Задачи:

- создание условий для формирования экологического сознания, экологической культуры обучающихся;

- организация социального партнерства;

- развитие у обучающихся качественно высокого уровня представлений о картине мира, основанных на общечеловеческих ценностях;

- организация проектной и исследовательской деятельности обучающихся;

- организация сетевого взаимодействия через ИКТ компетенции;

- социализация учащихся через реализацию проектной деятельности и привлечение обучающихся к конкурсам, фестивалям, форумам в области экологии.

\section{Концептуальная часть}

Экологические знания необходимы, прежде всего, для поддержания биологического разнообразия на планете, определения устойчивого сосуществования и развития биосферы и человеческого общества, сохранения жизни на Земле. Экологическое образование подразумевает формирование 
качественно нового мировоззрения людей, живущих в XX1 веке. Экологическая культура является составной частью общей культуры человека и может рассматриваться, как с экологической позиции, так и с культурологической.

Неотъемлемые черты экологической культуры-экологическое сознание и экологическое поведение. Главными показателями экологической культуры является способность человека пользоваться своими экологическими знаниями и умением применять их на практике.

Данная работа выстроена с учетом необходимости формирования у учащихся осознанной трансформации экологических знаний в убеждения, привитие навыков экологической культуры и экологического поведения.

Организация деятельности обучающихся осуществляется через следующие направления.

1. Урочная деятельность обучающихся. Создаются условия для повышения предметной мотивации расширения и углубления знаний об окружающем мире, формировании экологических компетенций. Используются формы организации учебной деятельности: урок как коллективное действие, консультация, презентация, конференция, интегрированный, учебное занятие (коллективное, индивидуальное, групповое, лабораторное).

2. Интегрированные занятия способствуют формированию экологического сознания обучающихся. Большую роль в этом играет интеграция уроков биологии с уроками химии, физике, географии, математике, литературы и др.

3. Внеурочная деятельность. Обучающиеся получают богатый социальный, нравственный опыт участия в коллективных и индивидуальных проектах природоохранной деятельности (в школе, регионе, на пришкольном участке, в городе), экологических акциях, десантах по созданию цветочных клумб, очистке доступных территорий от мусора, подкормке птиц и другой экологической деятельности, что способствует формированию гражданской идентичности учащихся через осознание и посильное решение экологических проблем. Для проектной и исследовательской деятельности обучающиеся выбирают разнообразные темы в основном практической направленности. Школьники овладевают предметом исследования, разрабатывают проекты, проводят опыты, эксперименты, опросы. Организация такой деятельности способствует успешному формированию универсальных учебных действий. 
Система данной работы позволяет воспитывать стремление к аргументированному обсуждению проблем, относящихся к естественным наукам и технологиям. Наиболее продуктивной формой представления проектов, обучающихся являются конференции различного уровня.

\section{Практическая часть}

Формированию экологических компетенций способствует авторская программа внеурочной деятельности «Гармония мира и природы».

Программа дает возможность к формированию активной жизненной позиции обучаемых, что предполагает гармоничное сочетание таких качеств, как самопознание, самореализация, творческое саморазвитие. Практические и экологические исследования дают, обучающимся богатейший материал, который успешно используется на конференциях, конкурсах.

Отличие данной программы в том, что обучающиеся знакомятся и исследуют экологические проблемы. Все образовательные блоки программы предусматривают не только усвоение теоретических знаний, но прежде всего формирование практических навыков. Выполнение практических заданий способствует развитию у обучающихся творческих способностей и наблюдательности, умению проявлять личное отношение к сохранению окружающей среды, активную жизненную позицию как гражданина своей Родины. Данная программа ориентирует на развитие у школьников экологического сознания, экологической культуры.

Программа предусматривает межпредметные связи экологии с биологией, географией, химией, физикой, математикой, литературой, информатикой и.т.д.

Основная цель данной программы - воспитание гуманного, творческого, социально активного человека, уважительно и бережно относящегося к среде своего обитания, формирование экологической культуры школьников.

Деятельность обучающихся выстраивается по следующим направлениям:

- создание условий для формирования экологического сознания, экологической культуры учащихся;

- организация социального партнерства;

- развитие у обучающихся качественно высокого уровня представлений о картине мира, основанных на общечеловеческих ценностях;

- организация проектной и исследовательской деятельности обучающихся; 
- организация сетевого взаимодействия через ИКТ компетенции;

- социализация учащихся через реализацию проектной деятельности и привлечение обучающихся к конкурсам, фестивалям, форумам в области экологии.

Реализация программы «Гармония мира и природы» осуществляется по разделам:

- влияние человека на окружающую среду;

- основы экологической этики;

- первые шаги в науку;

- социально-значимая деятельность;

- основы проектной и исследовательской деятельности;

- экологические уроки и экодиктанты.

При изучении раздела влияние человека на окружающую среду подразумевается знакомство с основными законами охраны окружающей среды, создание плакатов, листовок, викторин по страницам Красной книги. Особое внимание уделяется пониманию экологической безопасности. Одним из видов деятельности является организация тематических экскурсий, туристических походов и виртуальных путешествий по родному краю, участие в природоохранительной деятельности (в школе и на пришкольном участке, экологических акциях, высадка растений, создание цветочных клумб, очистка доступных территорий от мусора).

В разделе основы экологической этики организуются мероприятия, посвященные Дню здоровья. Создаются альбомы, книжки-малышки отражающие профессии эколого-биологической направленности.

Первые шаги в науку дают возможность вовлечь учащихся в мир олимпиад, проведению игр разума, викторин и конкурсов.

В разделе социально-значимой деятельности особое внимание уделяется развитию у обучающихся социальной активности через участия в акциях экологической направленности, организации помощи приюту для бездомных животных «Хатико» и подкорми птиц зимой.

Проектно-исследовательская деятельность способствует успешному формированию универсальных учебных действий. Результаты наших работ, обучающиеся представляют на различных уровнях: школьном, муниципальном, региональном, всероссийском (приложение 1).

Экологические уроки и экодиктанты открывают обучающимся знания о ценности жизни во всех ее проявлениях, о необходимости ответственного и бережного отношения к окружающей среде. 
Сложно представить внеурочную деятельность без взаимодействия с урочной. Поэтому урочная и внеурочная деятельность выстраивается с учетом познавательных процессов школьников.

Любая деятельность обучающихся начинается с его работы на уроке. А задача учителя так организовать урок, чтобы свой первый опыт юный исследователь приобрел под его руководством и при поддержке одноклассников.

Первые представления о научном исследовании обучающиеся получают уже в начальной школе. Задача основой школы - развить и углубить навыки наблюдения, сформировать такую особенность личности ребенка, как наблюдательность.

Естественным продолжением метода наблюдения является метод описания, овладение которым вызывает у детей определенные трудности. Хорошую помощь в формировании этого навыка оказывают разработанные памятки и планы для наблюдения и описания природных объектов (приложение 2).

Невозможно представить уроки биологии без проведения простейших экспериментов. Это и опыты с комнатными растениями при изучении процессов фотосинтеза и дыхания и опыт по выращиванию плесневых грибов и.т.д.

Одним из важных элементов является введение в сценарий урока проблемных вопросов и задач. Школьная программа по биологии дает возможность вынести на обсуждение с детьми множество проблемных ситуаций. Например, почему С.Г. Навашин назвал оплодотворение у цветковых растений двойным? Почему не разрешают собирать грибы и ягоды в заказниках, где разводят редкие виды животных?

Еще одна эффективная форма работы с обучающимися - обсуждение мини-докладов. Темы для докладов могут быть разнообразными: «растения пустыни», «строение клетки», «фотосинтез», а также творческие задания, например, написать сказку. Можно предложить обучающимся следующие темы: «откуда у бурундука полоски», «как соловей научился петь», «как змея потеряла ноги» и другие.

Выступление перед классом развивает у школьников навыки грамотной речи, умение вести себя во время публичного выступления, аргументированно отвечать на вопросы, отстаивать свою точку зрения, анализировать полученную информацию, рефлексировать собственную деятельность и деятельность одноклассников. 
Обучающиеся склонны к самоанализу, но зачастую они не умеют объективно оценить свою деятельность. Поэтому предлагаются инструменты - помощники в виде памяток, анкет для самоанализа, критериев ответа (приложение 3).

\section{Заключение}

Целенаправленная работа по формированию экологической компетенции имеет большое значение для развития функциональной грамотности. В процессе воспитания нравственного отношения к природе обучающимися осуществляется самостоятельный активный поиск и открытие знаний о ценности жизни во всех ее проявлениях, о необходимости ответственного и бережного отношения к окружающей среде. Наш современный ученик - это тот, кто завтра станет полноправным членом общества, осознает ценность и уникальность не только своей, но и чужой жизни, ощущает себя частичкой природы, умеет прогнозировать, просчитывать результаты своего воздействия на природу.

Как показывает наша практика, приобретенный в школьной жизни опыт, помогает не только развить способности обучающихся и сформировать необходимые компетенции, но и приводит в дальнейшем к профессиональному самоопределению. Наши обучающиеся являются успешными людьми в жизни. Это медики, экологи, прокуроры, инженеры, системные администраторы, психологи, юристы и т.д.

К сожалению, человеческое сознание меняется очень медленно. Нам не приходится рассчитывать на то, что своих целей по формированию экологического сознания мы достигнем очень быстро. Но кропотливая работа по формированию нравственного отношения к природе в итоге даст возможность обучающимся пользоваться своими экологическими знаниями и умениями в практической деятельности.

Формирование функциональной грамотности остается одним из ведущих направлений, так как перед педагогическим сообществом стоит задача научить выпускника школы объяснять явления, оценивать и планировать научные исследования, научно интерпретировать данные и доказательства. 


\section{Список литературы}

1. Игольницына Л.М. Эколого-валеологический практикум. Иркутск. Репроцентр А1. 2012 г.

2. Игольницына Л.М. Практическая экология для Сибиряков. Иркутск. Репроцентр А1. 2013 г. - 173 с.

3. Научно-исследовательский отдел развития образовательных систем. Правила техники экологической безопасности. Иркутск, 1994 г.

4. Либеров А.Ю. Экодидактика: Экосисистемная методология проектирования обучения. - М.: Институт экономических стратегий, 2007 г. $122 \mathrm{c}$.

5. https://nsportal.ru/shkola/materialy-metodicheskikhobedinenii/library/ 2019/10/29/ funktsionalnaya-gramotnost

6. https://fmc.hse.ru/data/2020/06/29.

7. https://multiurok.ru/files/vneurochnaia-deiatelnost-po-fgos.html

(C) Г.В. Бородина, 2021 